\title{
Working
}

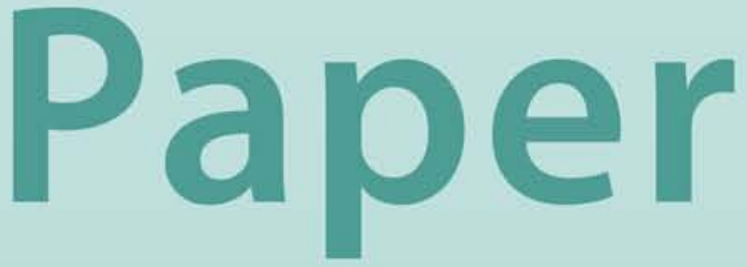




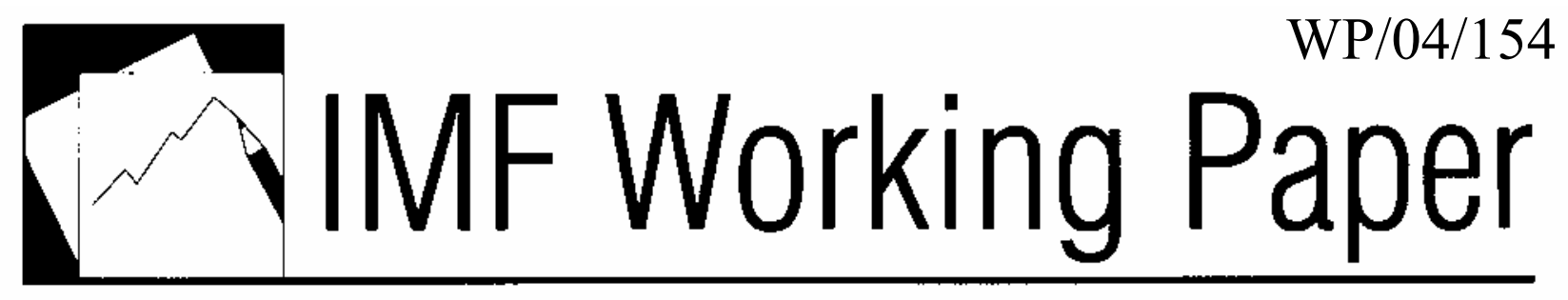

Measuring the Trade Effects of EMU

Hamid Faruqee

INTERNATIONAL MONETARY FUND 


\title{
IMF Working Paper
}

European Department

\section{Measuring the Trade Effects of EMU}

Prepared by Hamid Faruque ${ }^{1}$

Authorized for distribution by Albert Jaeger

August 2004

\begin{abstract}
This Working Paper should not be reported as representing the views of the IMF. The views expressed in this Working Paper are those of the author(s) and do not necessarily represent those of the IMF or IMF policy. Working Papers describe research in progress by the author(s) and are published to elicit comments and to further debate.

This paper examines the impact of European Economic and Monetary Union (EMU) on trade within the euro area. Using panel data for 22 industrial countries, the analysis estimates the effect of the euro's arrival on area-wide trade compared to bilateral trade flows between other industrial countries. Controlling for other influences according to the "gravity" model of trade, the panel analysis employs cointegration techniques to obtain reliable point estimates of EMU trade effects. Cross-country differences with respect to EMU trade gains and underlying factors accounting for these differences are also further explored.
\end{abstract}

JEL Classification Numbers: F15, F33, F34

Keywords: Currency unions, gravity model, bilateral trade

Author's E-Mail Address: hfaruqee@imf.org

\footnotetext{
${ }^{1}$ The author would like to thank Anthony Annett, Marcello Estevao, Albert Jaeger, and EUR seminar participants for helpful comments and discussions, and Alejandro Micco, Ernesto Stein, and Guillermo Ordoñez for graciously sharing their data. Any remaining errors are the author's.
} 


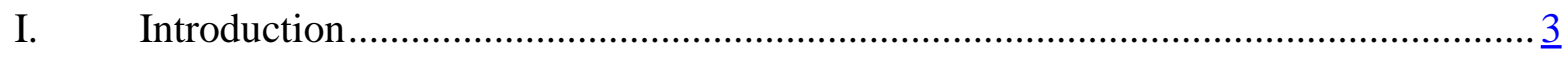

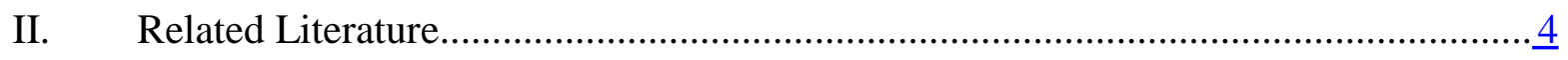

III. Recent Euro Area Trade Developments …..................................................

IV. Measuring the Trade Effects of EMU ….......................................................

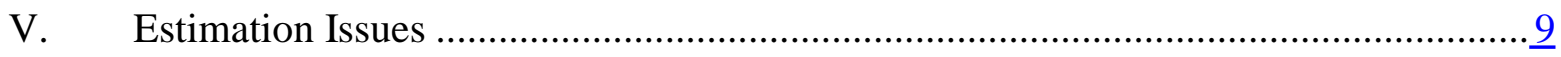

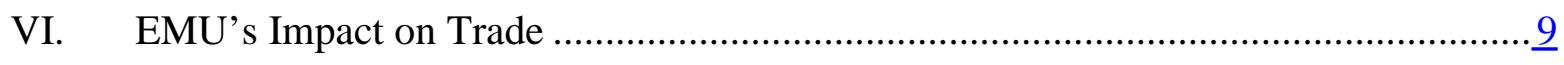

VII. Comparing EMU's Trade Effects Across Members States .................................. 11

VIII. Accounting for Cross-Country Differences in Trade Effects .............................. 15

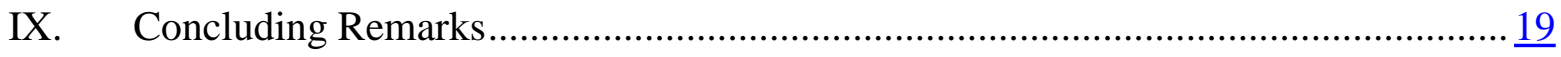

Appendix

I. Empirical Strategy ................................................................................ 21

II. Panel Unit Root Tests ............................................................................... $\frac{21}{23}$

III. Panel Cointegration Tests ................................................................... $\frac{23}{23}$

IV. Dynamic Panel Estimates ......................................................................

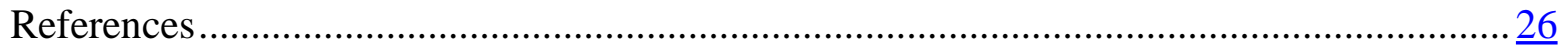

Tables

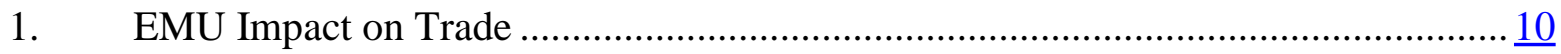

2. Area-Wide and Country EMU Trade Effects ................................................. $\frac{12}{18}$

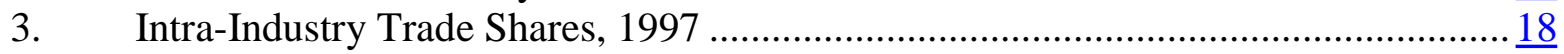

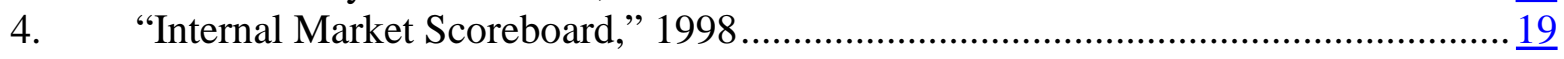

Appendix Tables

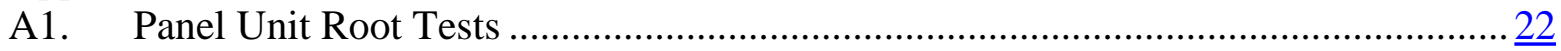

A2. Panel Cointegration Statistics ............................................................... $\frac{23}{25}$

A3. EMU Trade Effects and Country Deviations................................................ 25

Figures

1. Recent Trends in Euro-Area Goods Trade.............................................................. 6

2. Intra-Area Trade Gains under EMU ......................................................... 13

3. Dynamic Pattern of EMU Trade Effects............................................................... $\frac{14}{15}$

4. Trade Creation versus Trade Diversion Under EMU ........................................... $\frac{15}{17}$

5. Potential Determinants of EMU Trade Gains at the Country Level ......................... 17 


\section{INTRODUCTION}

As a catalyst for economic integration, Economic and Monetary Union (EMU) holds the promise of welfare gains for its member states. Among the potential benefits of monetary union, fostering further trade integration ranks very high. The argument that currency unions promote greater trade among members generally involves the following considerations: (1) lower (currency) transactions costs, (2) reduced exchange rate uncertainty, and (3) enhanced competition through greater transparency. But whether EMU has actually delivered on this score ultimately remains an empirical question that is the subject of this paper.

The issue takes on added significance with the recent enlargement of the European Union (EU) and the prospect of euro adoption by a wider group of countries. For these new EU members, the timing decision concerning when to initiate the process for euro entry hinges upon the perceived costs and benefits of joining the currency union. ${ }^{2}$ For them, and for older members who have not yet adopted the single currency, the potential trade benefits from EMU constitute an important consideration in that context. As part of the United Kingdom's "five tests," for example, trade gains offer one of the more compelling arguments for joining the euro area sooner rather than later. ${ }^{3}$ Lessons learned from the experience for current EMU members during the euro's first five years will help inform these historic decisions. ${ }^{4}$

This analysis provides a preliminary assessment of the trade impact of EMU. The central questions are as follows.

- $\quad$ Has monetary union fostered greater trade integration among member states? In particular, how large is EMU's impact on the area's trade flows?

- How have the trade effects of EMU evolved through time?

- $\quad$ Have the trade gains been evenly distributed among member states? If not, which countries have benefited relatively more, and have cross-country differences widened or narrowed?

- What policies and preconditions have been important in better positioning some euroarea countries to benefit more in terms of trade integration?

\footnotetext{
${ }^{2}$ See Schadler (2004).

${ }^{3}$ See U.K. Treasury (2003).

${ }^{4}$ See European Commission (2004) for a review of EMU's first five years.
} 
This last question highlights an often underemphasized part of the policy debate, related more to the operation (not formation) of a currency area. While much attention has been paid to issues related to optimal currency areas, this literature typically focuses on the question of whether countries should join or form a currency union. Given that the advent of the euro is now a part of history, the key question begins to shift from whether EMU will deliver on benefits for its members to which countries have benefited the most. More to the point, what aspects of the economic and policy setting are crucial to ensuring that the potential trade benefits of EMU membership become more than just a promise unfulfilled?

In considering these issues, one should bear in mind that EMU is best viewed as a process. While the introduction of the single currency was a well-defined event on January 1, 1999made tangible with the introduction of physical euro notes and coins on January 1, 2002 EMU has been an ongoing process that, in many ways, preceded the euro and, ultimately, will take many years to fully complete. Consequently, the subsequent analysis and assessment on trade should be taken as a "progress report" based on the evidence to date.

The remainder of the paper is organized as follows. The next section discusses the literature on currency unions and trade. Recent developments in external and internal trade flows for the European Union are then briefly reviewed to provide a broader context for the empirical analysis that follows. Following a description of the econometric framework and variables, panel estimates of the EMU trade effects at the area-wide and national levels are then examined. Determinants underlying cross-country differences with respect to trade gains is then further explored. The final section offers concluding remarks.

\section{RELATED LITERATURE}

The literature examining the impact of currency unions on trade is an extensive and active field of research. Much of the recent interest in the field was sparked by Rose (2000) who discovered the striking cross-section result that trading partners belonging to a currency union experienced a three-fold increase in bilateral trade compared to other trading partners, controlling for factors such as GDP or distance. This enormous positive effect sits somewhat at odds with the related literature that typically finds very little negative impact of exchange rate volatility on trade. ${ }^{5}$ Not surprisingly, the finding by Rose has received substantial scrutiny, and subsequent analysis generally finds a smaller (albeit still sizable) effect of currency union membership on trade. ${ }^{6}$

\footnotetext{
${ }^{5}$ Some studies even find positive effects of exchange rate volatility on trade. See Côté (1994) and McKenzie (1999) for surveys of this literature. See Clark, et al (2004) for recent analysis that underscores the traditional findings.

${ }^{6}$ For criticisms of the Rose methodology, see Persson (2001) and Teneryo (2001).
} 
Econometric issues aside, however, the implications for EMU of the Rose study are unclear for several reasons. First, the analysis did not directly include countries operating under EMU in the sample. Second, the sample countries that did belong to currency areas were mostly smaller, poorer countries. Finally, the cross-sectional analysis provides a comparative benchmark across trading partners that belong to an (existing) currency union arrangement against those that do not. But the more relevant issue for EMU surrounds the possible change in the level of trade for member states over time, before and after the introduction of the single currency. On this score, Glick and Rose (2002) analyze panel data to further exploit the time-series information associated with entering and exiting a currency union. They find that trade roughly doubles in that context, but again the sample does not cover the EMU experience.

The most relevant empirical study for the issues at hand is by Micco and others (2003), who directly examine the dynamic impact of EMU on trade. In a panel of 22 industrial countries and in a smaller panel of the 15 European Union member countries, the Micco study attempts to identify the direct contribution of the common currency on trade within the euro area. ${ }^{7}$ Their panel regressions, based on the gravity model, suggest that EMU has fostered further trade integration among member countries and that the positive effect has been rising over time.

Taking that analysis as a starting point, this paper addresses several economic and econometric issues in further examining the quantitative impact of EMU on trade. Taking account of possible non-stationarity in the data, the empirical analysis here relies on panel cointegration techniques that provide more reliable point estimates and interpretable standard errors in the presence of unit roots as a check on the standard least squares estimates. Second, the trade effects are examined more closely at the individual country level to assess how relative trade gains have been distributed among the EMU membership to evaluate whether these effects have been converging, and to help identify country factors that may underpin relative trade performance.

\section{ReCENT Euro Area Trade DeVElopments}

Against the backdrop of rising world trade and increasing globalization, trade flows to and from the euro area have also risen significantly over the past decade. Both intra- and extraarea trade in goods have steadily expanded as shown in Figure 1. Interestingly, although both types of trade have seen rising trends, external trade - with all, not only industrial, partner

\footnotetext{
${ }^{7}$ See European Commission (2003) for a recent review of studies examining the EMU impact on trade. The report estimates trade gains, based on a time-series model, between 7 and 18 percent.
} 
countries - has grown relatively faster in recent years, increasing as a share of total trade. ${ }^{8}$ When examining the effects of monetary union on bilateral trade flows in the ensuing empirical analysis, it will be useful to bear in mind these aggregate trends to place EMU trade effects within that broader context.

Figure 1. Recent Trends in Euro-Area Goods Trade $(\log$ index; January $1990=0)$
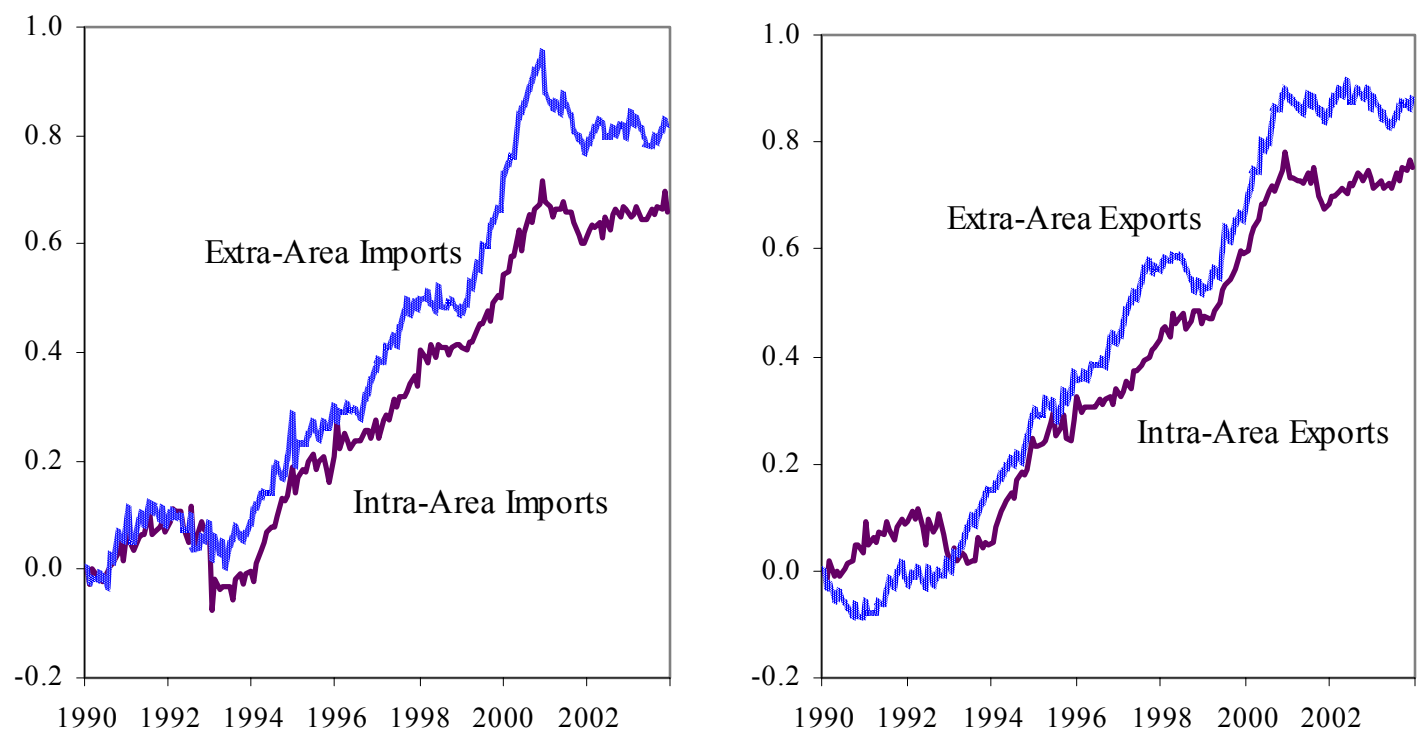

Source: Eurostat

\section{Measuring The Trade EfFects of EMU}

To isolate the effects of EMU on trade, one must first control for other factors that impinge upon trade flows but are otherwise unrelated to monetary union. To guide the selection of control variables, the gravity model of international trade is taken as a starting point. ${ }^{9}$ The gravity model predicts the bilateral trade flows should depend on factors such as economic

${ }^{8}$ Within the European Union (EU) - prior to its 2004 enlargement, aggregate flows between EMU member states have risen more sharply than trade between EU members not belonging to the euro area with their EMU trading partners. See European Commission (2003).

${ }^{9}$ The gravity model has enjoyed a long history of empirical success, including Lineman (1966) and Bergstrand (1985) and many others. See Rose (2004) for a review of 19 more recent studies examining currency unions effects in the gravity model. A theoretical exposition of the gravity equation can be found in Anderson (1979) and Deardorff (1984, 1998); the latter two papers show that the gravity model can be consistent with several theories of international trade. 
size or "mass," distance, and other related considerations. The basic panel equation can be expressed as follows:

$\ln \left(\right.$ Trade $\left._{i j t}\right)=\gamma_{i j}+\tau_{t}+\beta_{1} \ln \left(Y_{i t} Y_{j t}\right)+\beta_{2} \ln \left(y_{i t} y_{j t}\right)+\alpha F T A_{i j t}+\delta_{t} E U_{i j t}+\lambda_{t} E M U_{i j t}+\varepsilon_{i j},(1)$ where $\ln$ denotes the natural logarithm, Trade $_{i j t}$ is bilateral trade in goods between trading partners $i$ and $j$ at time $t, \gamma_{i j}$ represents the fixed effect in trade between partner countries $i$ and $j, \tau_{t}$ represents common time effects for a particular year, $Y$ and $y$ represent gross domestic product in level and per capita terms, FTA is a dummy variable for free trade agreements, $E U$ and $E M U$ are dummy variables equaling one if both partners belong to the EU or the euro area respectively and zero otherwise, and $\varepsilon$ is the error term. ${ }^{10}$ The coefficient $\lambda$ in equation (1) is the central parameter of interest.

The fixed effect is intended to capture all individual fixed factors - including unobservable characteristics - associated with a given country pair that have affected bilateral trade flows historically. These time-invariant factors includes geographical distance, area, common language, common border, etc. ${ }^{11}$ The advantage of fixed effects estimation over directly including these specific measures is controlling for omitted variables bias at the expense of isolating the individual contribution of (say) distance on trade. ${ }^{12}$ The time effects are intended to capture common time developments with respect to bilateral trade across all trading partners in the panel. For example, the special case of a linear time trend in trade shares (e.g., increasing global integration) would be captured by the inclusion of time effects.

Other control variables entering the regression are the standard gravity variables related to economic size and population. These are represented by (the logarithms of) the product of GDPs $\left(Y_{\mathrm{i}} Y_{\mathrm{j}}\right)$ and GDPs per capita $\left(y_{\mathrm{i}} y_{\mathrm{j}}\right)$ in the two trading partner countries. Typical gravity equation estimates find that these coefficient sum to unity; see Micco, et al (2003). Other control variable typically used in this type of regression include common membership in a free trade agreement $\left(F T A_{\mathrm{ijt}}\right)$. This dummy variable takes the value one in those years that both countries $i$ and $j$ maintain a free trade agreement and is zero otherwise. To the extent that these agreements are made or dissolved during the sample period, this variable is distinct from the (time-invariant) country-pair fixed effect.

\footnotetext{
${ }^{10}$ Total bilateral trade between trading partners $i$ and $j$ is based on merchandise exports and imports between $i$ and $j$, obtained from Direction of Trade Statistics; see Micco, et al (2003).

${ }^{11}$ A lengthy list of time-invariant factors can be found in Glick and Rose (2002), and Micco, et al (2003).

12 See Micco, et al (2003) and UK Treasury (2003) for fuller discussion of the advantages of fixed effects in the gravity trade model.
} 
The last control variable is membership in European Union. The variable $E U_{\mathrm{ijt}}$ takes the value one if both trading partner countries are members of European Union in that year and is zero otherwise. ${ }^{13}$ This measure is intended to control for the trade impact of the EU's Single Market Program as distinct from (but complementary to) the implications of monetary union. Consequently, the impact of EMU on trade should reflect the effects of the single currency above and beyond the implications of the Single Market Program. In addition to the EU variable, Micco, et al (2003) also include a linear time trend for EU partners to further capture the dynamic effects of EU membership through time. Equation (1) generalizes this specification by including EU "time effects"-i.e., time-specific coefficients on $E U_{\mathrm{ijt}}$-in the estimation.

Finally, the key variable of interest is represented by euro area membership $E M U_{\mathrm{ijt}}$, which equals one if both trading partners belong to the euro area in year $t$ and zero otherwise. A static variant of the monetary union variable is also considered: $E M U_{\mathrm{ij}}$ (without $t$ subscript), to measure the common average effect of adopting the single currency between 1999 and 2002. In the former specification, some years prior to 1999 are also included to examine whether some effects of monetary union might have preceded or anticipated the introduction of the euro. Note that the relevant "treatment groups" associated with EU and EMU are different. Specifically, European trading partners that include Denmark, Sweden or the United Kingdom are excluded from the EMU grouping. Based on the definition of the other regressors, the coefficient(s) on the EMU variable(s) have the following interpretation. The coefficient $\lambda$, or the set of coefficients $\left\{\lambda_{t}\right\}$, represent the effects of EMU on trade between member states relative to their industrial country peers (including extra-area trade), after controlling for the effects of economic size and population, free trade agreements, membership in European Union, individual country-pair fixed effects (e.g., distance, common language, area, etc.), and common time effects (e.g., time trend).

The panel consists of annual data from 1992-2002 for 22 industrial countries. ${ }^{14}$ The total number of country pairs or combinations from a sample of twenty-two countries is $C(22,2)=231$. Hence, the cross-section dimension of the panel dataset is $N=231$ and the time-series dimension is $T=11$, yielding a total number of observations $N T=2541$. Of these, 1263 observations or 50 percent record a free trade agreement between trading partners, 893 observations or 35 percent are EU trading partners, and 180 observations or 7 percent are between formal EMU trading partners (i.e., for years 1999-2002) excluding Greece.

${ }^{13}$ Note that only a few instances of countries joining the EU occur during the sample period. In terms of EU affiliation (or its antecedents), Belgium-Luxembourg, Denmark, France, Germany, Greece, Ireland, Italy, Netherlands, Portugal, Spain and United Kingdom joined prior to the start of the sample in 1992. Only Austria, Finland and Sweden joined within the sample period-i.e., in 1995.

${ }^{14}$ See Micco, et al (2003) for a detailed description and data sources. 


\section{ESTIMATION ISSUES}

Estimating the impact of monetary union on trade is confronted by several econometric challenges. First, possible endogeneity of right-hand side variables is certainly pertinent in this context. Frankel and Rose (2000), for example, specifically examine the purported impact of trade on income, whereas the gravity model specifies a causal relation in the other direction. Second, given the variables entering the gravity model, the possibility of unit roots may be relevant. Indeed, panel unit root tests provide non-negligible evidence of nonstationary data in this context (see appendix).

Because of the important quantitative aspect of the analysis, a robust empirical procedure is needed that can address these various concerns. Consequently, the empirical strategydetailed in the appendix - addresses the issue of unit roots and cointegration in a panel context, and then relies on the panel dynamic OLS (DOLS) estimation to generate reliable point estimates in the presence of non-stationary data and possible simultaneity bias as a check on the standard OLS estimates.

\section{EMU'S IMPACT ON TRADE}

Panel OLS and DOLS estimates of EMU trade effects are shown in Table 1. Note that in the case of unit roots, the OLS standard errors reported in the table are only indicative and the point estimates could be biased. In general, the DOLS point estimates are lower than their OLS counterparts and the corrected standard errors are significantly higher, again suggesting that care is needed in drawing statistical inferences based on OLS. Nevertheless, the average impact of EMU on intra-area trade flows is positive and, based on the DOLS standard errors, statistically significant at the 5 percent level. The point estimates suggest that EMU has raised intra-area trade by an average of 7-8 percent relative to other trade among industrial countries. Based on the estimates of the dynamic effects, the trade impact of EMU has been largest and statistically significant in the last two years 2001 and 2002. With panel DOLS, note that the impact of free trade agreements now has the correct sign although it remains statistically insignificant. Also note that the impact of GDP per capita (implicitly, population) in trading partners is not significant at the 5 percent level, in contrast to the impression given by the panel OLS estimates. Individual EU time effects (not reported) are positive-average effect $=1$ percent, albeit not significant at standard thresholds. ${ }^{15}$

${ }^{15}$ To examine possible multi-collinearity between the EMU variable and the sequence of EU time effects, the regressions were re-run after dropping one or the other. The EMU variable remains significant in the presence or absence of EU time effects, but the reverse is not true. 
Table 1. EMU Impact on Trade

Notes: Number of Observations $=2541 ; N=231 ; T=11$. All specifications include fixed effects, time effects, and EU time effects. Standard errors given in parentheses; OLS standard errors are only indicative under the null of non-stationarity. $\mathrm{A}^{*}\left({ }^{* *}\right)$ indicates significance at the 5 (1) percent level using adjusted standard errors.

To investigate robustness, several alternative empirical specifications were considered, but the finding of significant EMU trade effects remain intact. Replacing real GDP and GDP per capita variables by their nominal counterparts would raise the EMU trade impact to 12 percent at a significance level of 1 percent based on the DOLS estimates. Moreover, the dynamic impact of the euro on intra-area trade flows in that case becomes statistically significant earlier (1999 versus 2001). Allowing greater heterogeneity in the impact of the gravity variables - i.e., allowing coefficients to differ between EMU and non-EMU trading partners - does not overturn the significantly positive impact of EMU membership on trade flows.

The EMU effect on intra-area trade is larger if extra-area trade is also included in the estimates. If EMU effects on extra-area trade are also included in the estimation - by using another dummy variable which equals one if exactly 1 trading partner is a member of the euro area - the point estimate on intra-area trade rises (to 14 percent). The reason is a follows. Like intra-trade, extra-area trade has also grown faster in relative terms (albeit to a lesser degree) when compared to other industrial country trade flows. Consequently, excluding extra-trade from the control group raises the estimated EMU impact on trade 
between member states when measured relative to trade between partner countries sitting exclusively outside the euro area. This also suggests that monetary union has not had trade diverting effects - an important issue when considering the overall welfare implications, since both intra- and extra-area trade have gained on a comparative basis under the single currency. ${ }^{16}$

\section{Comparing EMU's Trade EfFects Across Members States}

The empirical framework can also be used to further examine whether the EMU trade impact is similar across individual member states. Specifically, relaxing the restriction that imposes a common effect of EMU membership on trade, the estimation can allow for country-specific effects using the following variables. Interacting country dummies with the EMU variable (e.g., $S P A I N^{*} E M U$ ), a new variable is constructed to isolate the trade impact for each euro area economy (combining Belgium and Luxembourg and excluding Greece). The aggregate EMU variable is then conformably redefined to exclude that same member country (e.g., "EMU less Spain"), based on the difference between the two dummy variables (e.g., EMU $\left.S P A I N^{*} E M U\right)$. The estimation is repeated for each member state, identifying its individual EMU impact in this way. The results based on DOLS estimation are reported in Table 2.

The trade gains under monetary union show wide dispersion at the country level, but the overall trade creating effects of EMU are not due to individual outliers. As a further robustness check, the effects of European monetary union on area-wide trade remain statistically significant when each member state is excluded individually from the area-wide variable. The average trade gain ranges from 6 to $9 \frac{1}{2}$ percent in Table 2 , depending on the member state that is excluded. From the country perspective, the results further suggest that the trade gains from the euro have not been evenly distributed among member states. Figure 2 displays the distribution of trade gains at the country level under EMU reported in Table 2. Spain and Netherlands record significantly larger trade gains than the average. Meanwhile, three countries have underperformed: Ireland, Finland, and Portugal. The country-specific impact - expressed as a negative deviation from the aggregate EMU effect — is statistically significant for the latter two countries. ${ }^{17}$

${ }^{16}$ See also Micco, et al (2003).

${ }^{17}$ Using the original EMU variable, in lieu of the re-defined measure, in the regression normalizes the country-specific EMU variable as a deviation from the average - i.e., the relative trade impact. The "deviations" table is included in the appendix. 


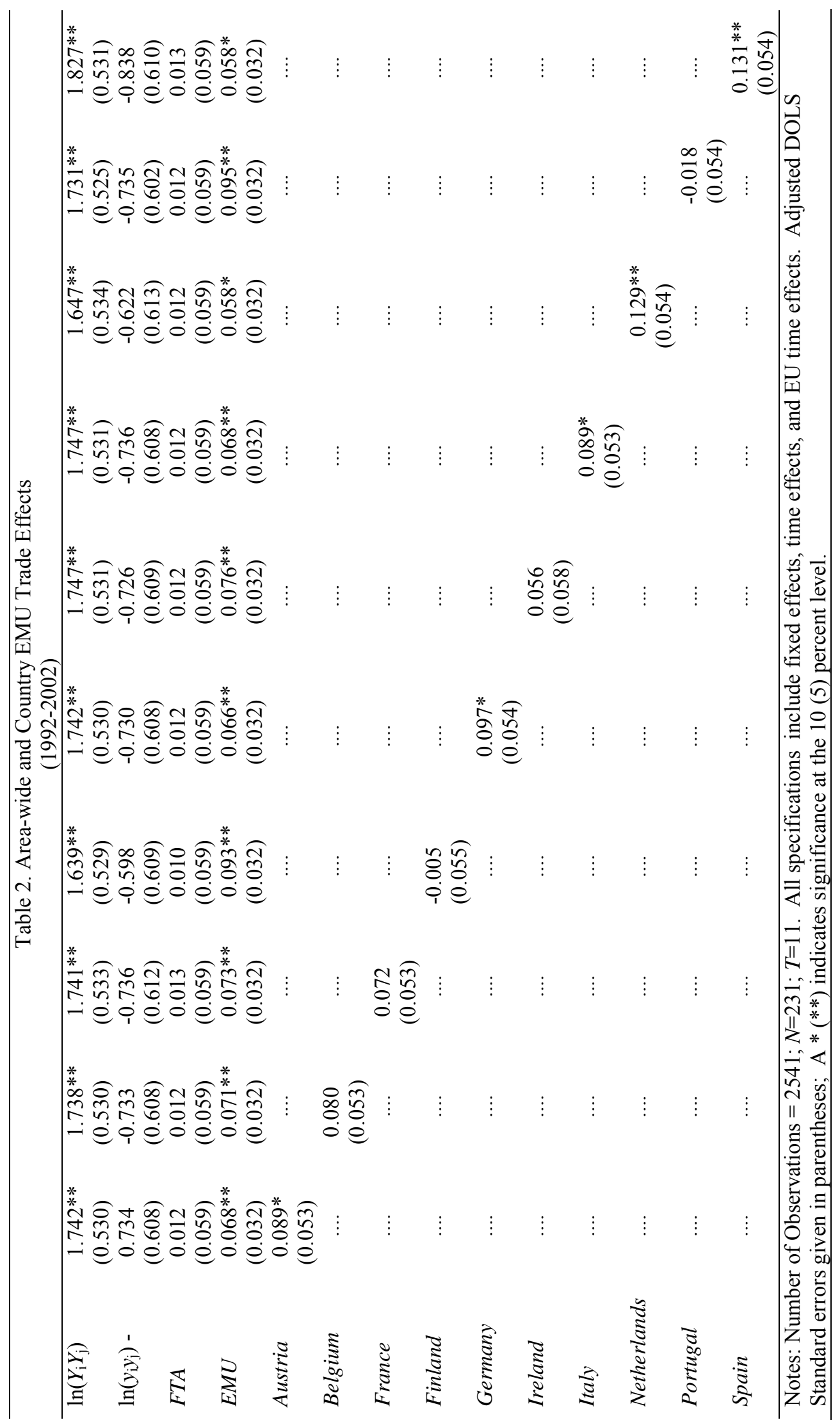


Figure 2. Intra-Area Trade Gains under EMU

(In percent)

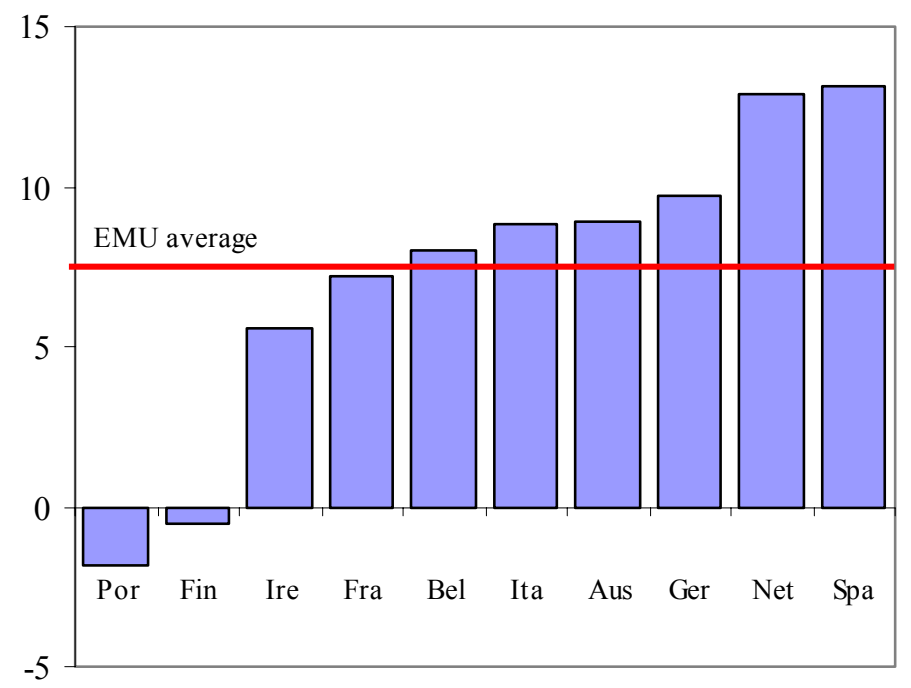

Source: IMF Direction of Trade Statistics and staff estimates

Dynamic estimates of EMU effects show rising, but disparate, trade gains across individual member states. Repeating the country estimation procedure but with time-varying coefficients, the time pattern of EMU trade effects at the area-wide and national levels are shown in Figure 3. The overall EMU trade impact (thick solid line) is equal to the average of the individual country effects. From the figure, the three largest economies generally display dynamic trade effects in line with the average. But considerable dispersion around the average exists for the smaller countries. Spain and the Netherlands have generally outpaced the average trade gains under EMU. Meanwhile, Portugal, Finland and, to a lesser extent, Ireland have lagged.

The dispersion of trade effects is not declining over time for the smaller euro area economies. Specifically, the cross-sectional standard deviation of country point estimates in 2002 is about twice that in 1999. As evident from the figure, some countries have been (and remain) better positioned to reap the trade benefits from the single currency, and these differences do not appear to be narrowing. This lack of convergence finding suggests that the overall trade gains from monetary union can vary in a persistent fashion within the EMU membership. 
Figure 3. Dynamic Pattern of EMU Trade Effects

(In percent)
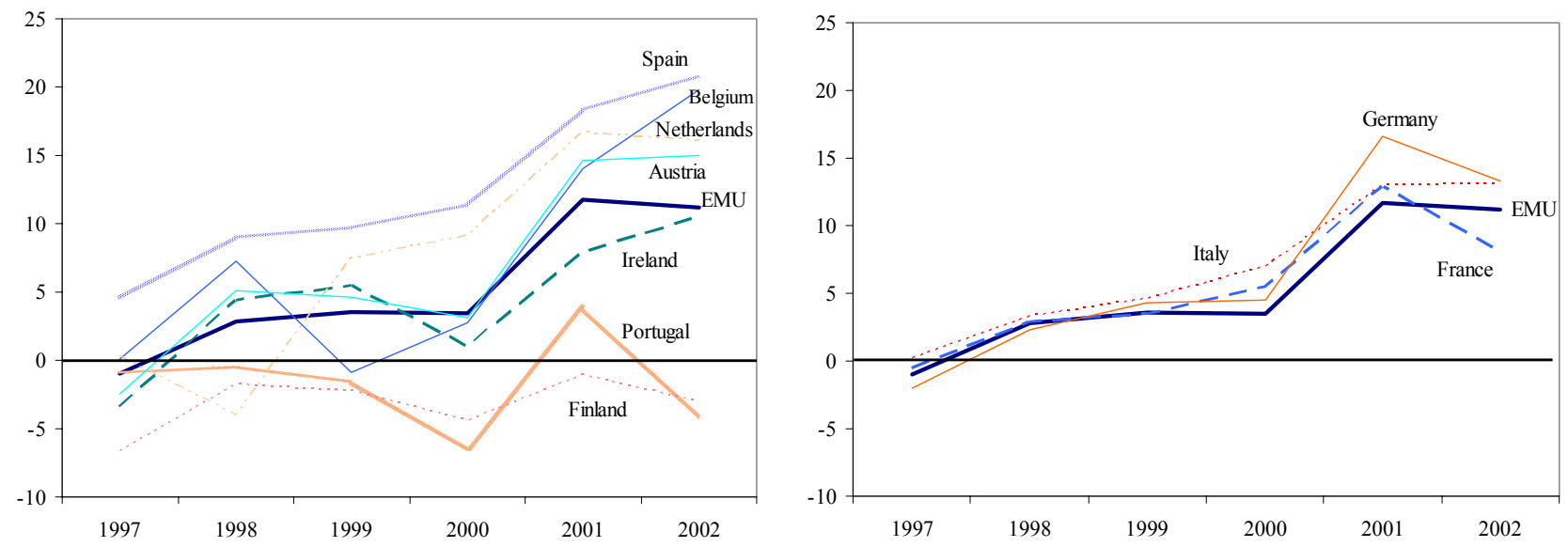

Source: IMF Direction of Trade Statistics and Staff estimates.

Returning to the issue of trade creation versus trade diversion, gains in extra-area trade under EMU have also varied across countries. Though extra-area trade flows have increased overall, here too, the distribution of gains at the country level has been uneven. Figure 4 shows the average trade impact on both intra- and extra-trade fronts since 1999, using the same pairwise comparison of EMU-wide and country-specific effects. Overall, average gains to intra-area trade and extra-area trade are estimated to be 14 and 8 percent, respectively. Around these averages, though, significant cross-country dispersion exists. Interestingly, Ireland, which has under-performed with respect to intra-area trade gains, outperforms in the realm of extra-area trade. Portugal and Finland, in contrast, lag in both trade dimensions. 
Figure 4. Trade Creation versus Trade Diversion Under EMU (In percent)
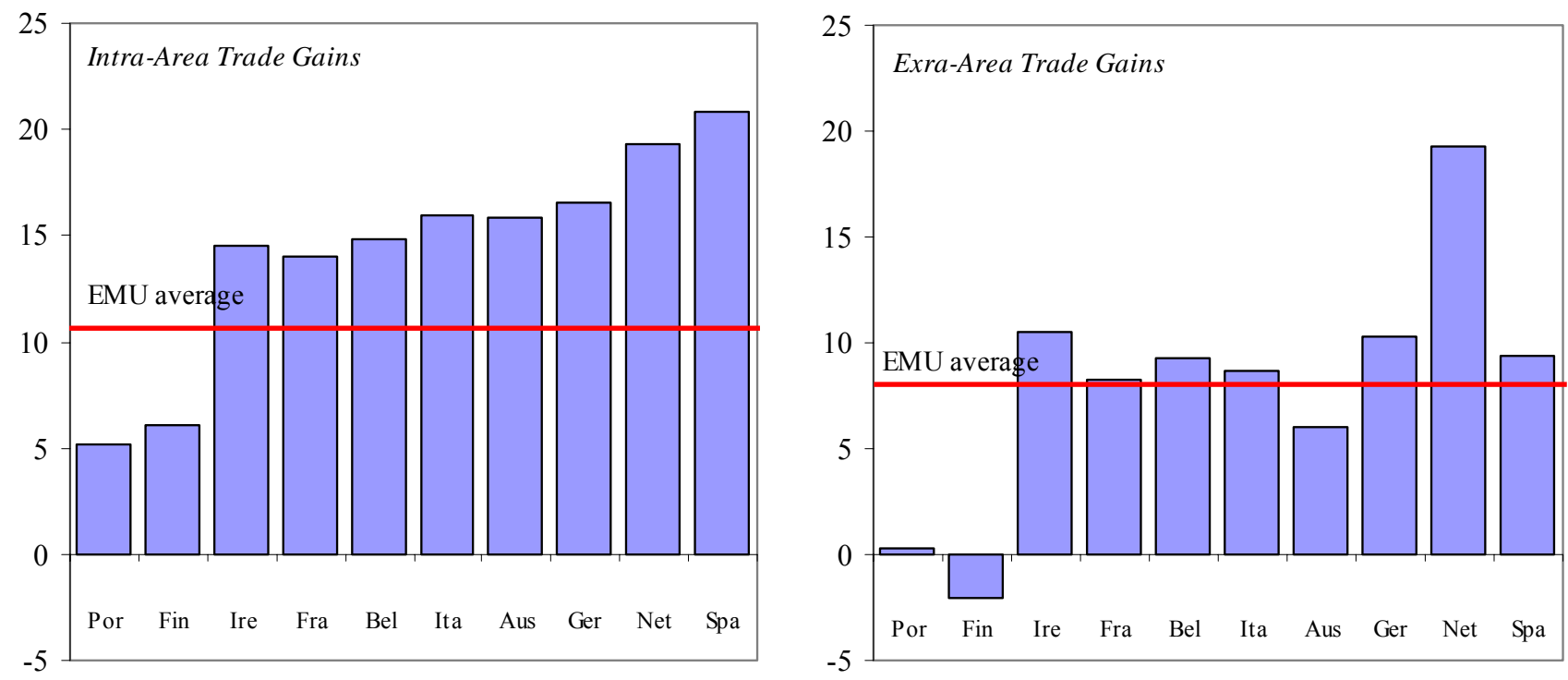

Source: IMF Direction of Trade Statistics and Staff estimates.

\section{ACCOUnting For Cross-Country DifFerences in Trade EFFECTS}

Determining the sources of underlying country differences with respect to the trade gains from EMU may yield several important insights. A better understanding of the proximate causes that have differentiated country experiences could shed light on the key mechanisms through which monetary union has benefited trade. While a vast literature has explored the trade effects of currency unions, much less is known about the major channels through which such effects occur. The apparently incongruent findings between the currency union literature and the trade volatility literature only illustrates our ignorance on this issue. From a policy standpoint, delving into the causes underpinning country differences in trade performances would help further identify policy priorities that could orient economies to better take advantage of the potential gains that may accrue with currency union membership.

Explanations for country disparities likely rest on a confluence of factors rather than on any single determinant. The trade implications of monetary union for individual member states likely involves the interplay of a many factors and channels. Given broad agreement on the possible mechanisms through which a currency union is thought to affect trade integration, candidate explanations that may help explain cross-country differences include: 
- $\quad$ Trade openness. Countries that have greater exposure to trade may stand to benefit relatively more from the creation of the euro, although the "base effect" may make additional trade gains (in percentage terms) more difficult to achieve.

- $\quad$ Trade patterns. Certain types of trade may benefit to a greater extent from a common currency. Frankel and Rose (1998), for example, argue that intra-industry trade should flourish within the euro area. ${ }^{18}$ Correspondingly, countries with higher initial shares of intra-industry trade may be better placed to benefit at the outset.

- $\quad$ Exchange rate volatility. Countries with higher volatility in their exchange rates prior to monetary union presumably would benefit to a larger extent from the decline in exchange rate uncertainty.

- Market flexibility and reforms. Countries with more fluid adjustments in shifting resources and production to sectors that enjoy comparative or competitive advantage might be better positioned to see larger trade gains.

Figure 5 presents simple plots of bi-variate regressions relating EMU trade gains to various potential determinants. The cross-sectional regressions relate country estimates of trade gains under EMU to the initial share of EU exports, initial share of intra-industry trade within the EU, past nominal effective exchange rate volatility, and the implementation deficit in the Internal Market program. The figures also report the $R^{2}$ and slope coefficients associated with these regressors. Given the paucity of observations, these bivariate regressions should only be interpreted as broadly indicative. ${ }^{19}$ In general, the variables have the right sign though only trade patterns and product market reforms appear significant and account for some of the country variation in trade gains. These two factors are discussed in more detail below.

${ }^{18}$ See also European Commission (2002).

${ }^{19}$ Standard errors (not reported) on the slope coefficient are also only indicative, given that the dependent variable is estimated - i.e., measured with error - and not directly observed. 
Figure 5. Possible Determinants of EMU Trade Gains at the Country Level
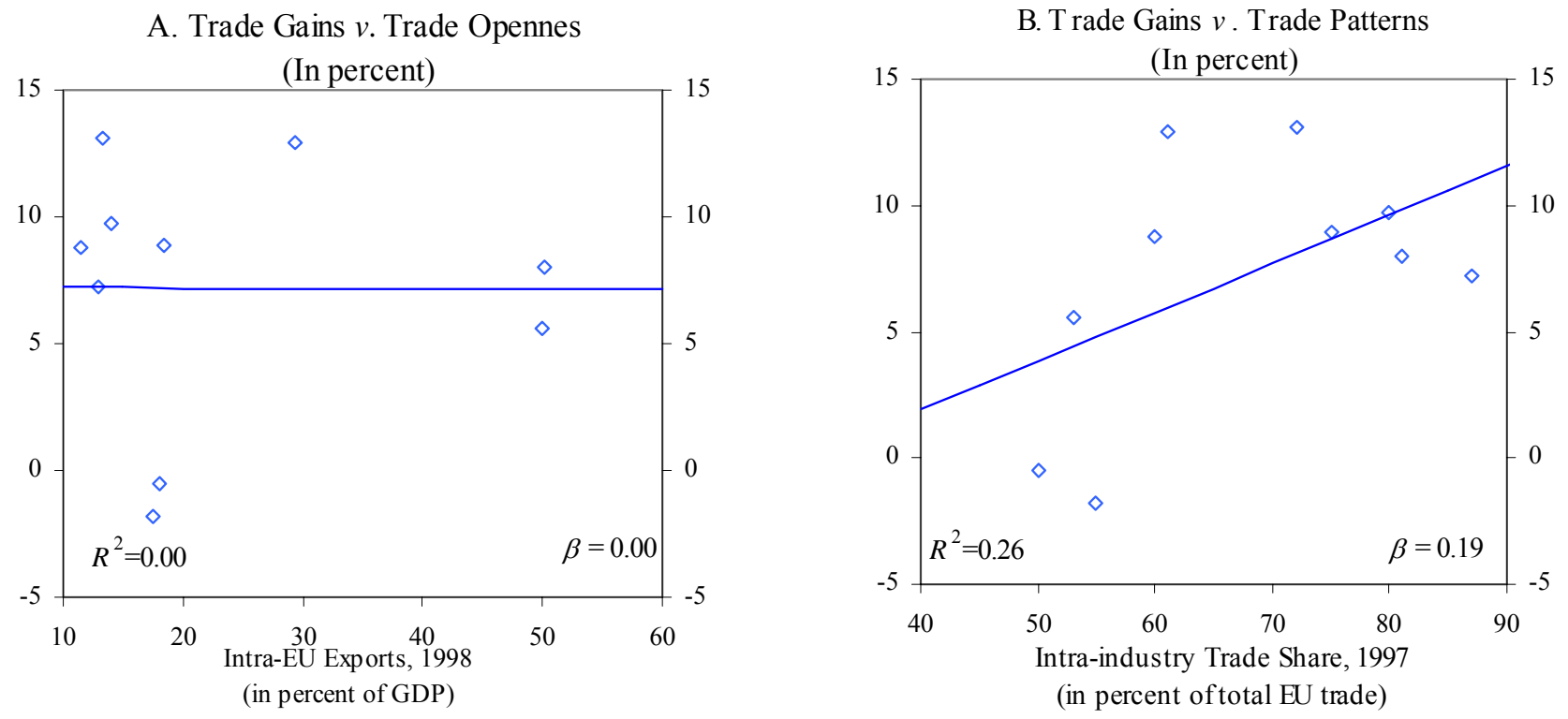

C. Trade Gains $v$. Exchange Rate V olatility

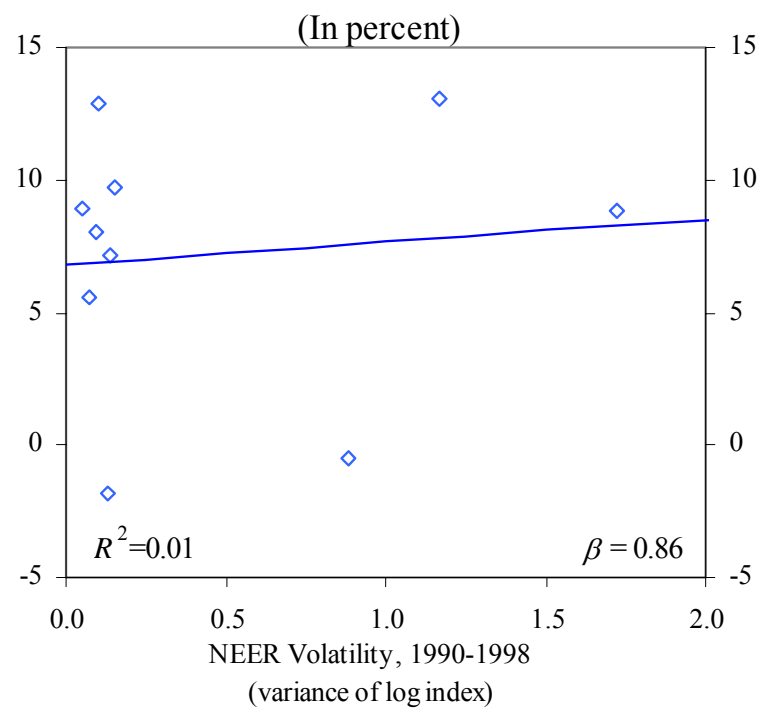

D. Trade Gains $v$. Product Market Reforms

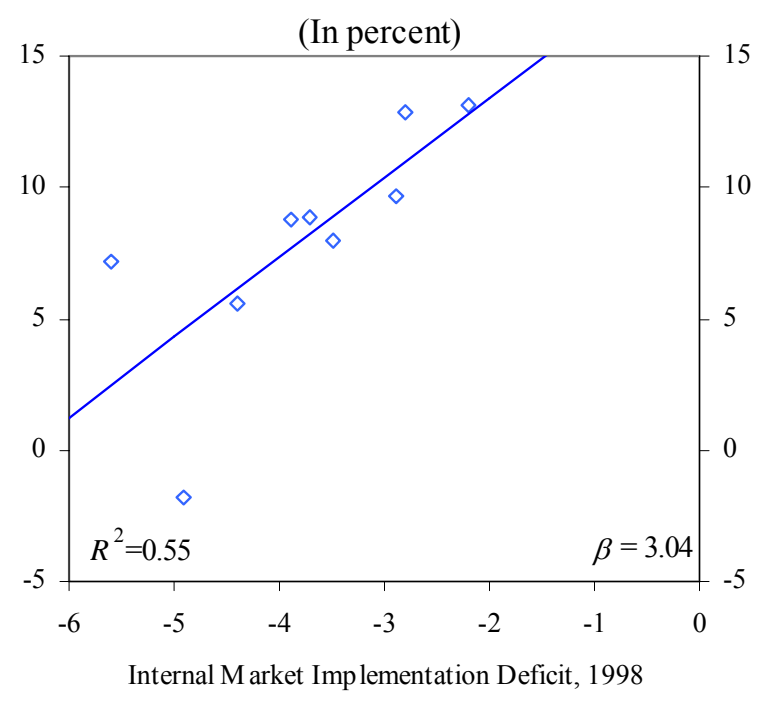


The role of intra-industry trade appears to be an important contributing factor behind country differences with respect to EMU trade gains. This type of trade tends to be sensitive to exchange rate variability, since two-way trade in similar products suggests greater substitutability between home and foreign goods and, thus, greater sensitivity to relative price changes. ${ }^{20}$ At the start of EMU, countries with higher existing shares of intra-industry trade within Europe appear to have benefited more from the virtual elimination of exchange rate uncertainty since the euro's arrival (see Figure 5b). Table 3 presents intra-industry trade shares for euro area member states in 1997. A number closer to unity indicates a higher share of two-way trade as a percent of total trade with EU partners. Remarkably, the countries with the lowest initial shares of intra-industry trade - Ireland, Finland, and Portugal — are the same three countries that appear on the low end in terms of relative trade gains. Austria, Germany, Spain and, for more recent years, Belgium have had above-average trade gains from monetary union, and all have intra-industry trade shares that are above average $(=67$ percent). The relative gains for Spain, though, appear somewhat exceptional. Initial intraindustry trade presence also appears less relevant in understanding the respective experiences of the Netherlands, Italy and France. Based on the regression, about one-third of the variation in trade gains appears accounted for by initial trade patterns.

Table 3. Intra-Industry Trade Shares, 1997

\begin{tabular}{lc} 
& $(\text { In percent })^{1}$ \\
\hline Finland & 50 \\
Ireland & 53 \\
Portugal & 55 \\
Italy & 60 \\
Netherlands & 61 \\
Spain & 72 \\
Austria & 75 \\
Germany & 80 \\
Belgium & 81 \\
France & 87
\end{tabular}

I Grubel-Lloyd index measures share of intra-industry trade in percent of total trade with EU trading partners. Source: European Commission (2002).

Trade gains under monetary union may also depend on underlying policies that address market flexibility. Policy-related considerations - such as those affecting factor mobility and firm entry and exit costs - could play an important role in generating the necessary resiliency

${ }^{20}$ See, for example, Fontagne and Freudenberg (1999). See Faruqee (1996) for a theoretical discussion. 
and adaptability for countries to tackle the prospects and challenges of greater trade integration under monetary union. Given the crude measures that are typically available, though, inference on the basis of statistical regressions should be done cautiously. Table 4 reproduces the European Commission's "scoreboard" reporting the implementation deficit of the Internal Market Program prevailing just prior to the advent of the euro. In general, a lower implementation deficit correlates well with higher trade gains - with the notable exception of Finland-generating a good fit in Figure $5 \mathrm{~d}^{21}$

Table 4. "Internal Market Scoreboard," 1998

\begin{tabular}{lc} 
& $($ In percent) \\
\hline France & -5.6 \\
Portugal & -4.9 \\
Ireland & -4.4 \\
Italy & -3.9 \\
Austria & -3.7 \\
Belgium & -3.5 \\
Germany & -2.9 \\
Netherlands & -2.8 \\
Spain & -2.2 \\
Finland & -1.7 \\
\hline 1998 implementation deficit with respect to EU laws under the Internal Market Program. \\
Source: European Commission.
\end{tabular}

\section{CONCLUDING REMARKS}

This analysis has sought to measure the impact of monetary union on trade in the euro area in relation to trade among its industrial country peers. Controlling for the influences of economic size, population, and other factors, the panel analysis provides a "progress report" on the likely impact of the European common currency on bilateral trade within the euro area. Preliminary conclusions are as follows:

- $\quad$ EMU has had a positive impact on intra-area trade. Based on the panel evidence, monetary union has boosted trade among member states by roughly 10 percent during the euro's existence. This effect is in line with more conservative estimates of currency union effects and some estimates of exchange rate volatility effects on trade.

${ }^{21}$ Figure $5 \mathrm{~d}$ excludes Finland, which is a significant outlier. Including it in the regression would still yield a positive slope coefficient, but worsen the fit drastically (i.e., $R^{2}=0.05$ ). 
- $\quad$ The gains in intra-area trade do not appear to occur at the expense of extra-area trade. In other words, EMU seems to have had trade-creating effects not trade-diverting effects.

- $\quad$ The dynamic effects of European monetary union on trade integration appear to be rising over time. Consequently, the estimates should be interpreted as the tradecreating effects thus far.

- $\quad$ The trade gains from the single currency have not been evenly distributed among member states. While the three largest euro area economies generally display trade gains similar to the average, considerable dispersion around this estimate exists for the smaller countries.

- $\quad$ Spain, the Netherlands, Austria, and, more recently, Belgium have generally outpaced the average trade gains under EMU. Meanwhile, Portugal, Finland, and Ireland tended to lag, although, in the last case, growth in extra-area trade has significantly outperformed that in other member states.

- The dispersion of trade gains have not narrowed over time for smaller euro area economies. Some countries have been (and remain) better positioned to reap the trade benefits from the common currency. This highlights the importance of not taking for granted the trade gains from a currency union, but rather focusing on the conditions and policies that help an economy realize the potential benefits.

- $\quad$ Accounting for country disparities likely rests on a confluence of factors, including policies that enhance market flexibility and initial conditions such as the pattern of trade. On the former, policies that help facilitate factor and firm mobility toward sectors that enjoy comparative or competitive advantage are likely to help economies adapt to the competitive challenges and opportunities under the common currency. On the latter, there appears to be a significant correlation between trade gains from EMU and the share of intra-industry trade, which tends to be more sensitive to relative price changes and, hence, exchange rate variability. Countries that have engaged predominantly in intra-industry trade within Europe have seen their areawide trade flows expand faster under the euro. 


\section{APPENDIX}

\section{Empirical Strategy}

Because of the quantitative importance of the empirical analysis, a robust estimation procedure, particularly to the possible presence of unit roots, is critical. And with nonstationary panel data, the specter of spurious regressions à la Granger and Newbold comes to fore in the absence of cointegration. ${ }^{22}$ Finally, even with cointegrating variables, ordinary least squares (OLS) estimates of equation (1) may lead to biased point estimates and non-standard $t$-statistics, impairing statistical inference. ${ }^{23}$ Consequently, the empirical strategy proceeds as follows:

- $\quad$ Determine the order of integration of variables through panel unit root tests;

- $\quad$ Test for cointegration among integrated variables through panel cointegration tests;

- Use panel cointegration estimators that address simultaneity bias and serial correlation to provide reliable point estimates and interpretable standard errors. ${ }^{24}$

\section{Panel Unit Root Tests}

Several panel unit root tests are conducted to test for the order of integration of variables entering the gravity equation. The two most popular panel unit root tests, based on the augmented Dickey-Fuller (ADF) tests, are the Levin, Lin and Chu (2002) (LLC) test, and Im, Pesaran and Shin (1997) (IPS) test. Both tests take nonstationarity in all panel series as the null hypothesis. The LLC test is based on pooled estimates (i.e., a common autoregressive coefficient), suggesting an alternative hypothesis of stationarity in all panel units. The lessrestrictive IPS test is based on group estimates (i.e., average of individual autoregressive coefficients); hence, the alternative hypothesis is that a fraction of panel units are stationary. The last panel unit root test, based on Hadri (2000), takes stationarity (unit root) instead as the null (alternative) hypothesis, based on group estimates of the familiar KPSS test. All tests

${ }^{22}$ Kao (1999) studies the spurious regression issue in a panel context.

${ }^{23}$ See Kao (1999) and Kao and Chiang (2000).

${ }^{24}$ An alternative approach would be to take first-differences to render the data stationary. However, this approach would turn the focus to the impact on trade growth rather than levels and raises other issues with first-differencing - e.g., less favorable signal-to-noise ratio and, consequently, the need for time-averaging or pre-filtering of the data. See, for example, Bayoumi and Eichengreen (1995). 
assume cross-sectional independence across panel units beyond common time effects. Table A1 reports the normalized test statistics which are all unit normally distributed or $N(0,1)$.

Table A1. Panel Unit Root Tests

\begin{tabular}{llll}
\hline \hline & $L L C$ & IPS & Hadri \\
\cline { 2 - 2 }$\left(\right.$ trade $\left._{\mathrm{ij}}\right)$ & -0.07 & $-6.21^{* *} 13.54^{*}$ & ${ }^{*}$ \\
$\operatorname{Ln}\left(Y_{\mathrm{i}} Y_{\mathrm{j}}\right)$ & 4.18 & -1.04 & $14.41^{* *}$ \\
$\operatorname{Ln}\left(y_{\mathrm{i}} y_{\mathrm{j}}\right)$ & 2.14 & $-3.86^{* *}$ & $14.52^{* *}$
\end{tabular}

Notes: Sample period 1980-2002. Panel unit root test include time and fixed effects. Lag length chosen by data dependent methods, testing down from maximum number of lags (6). An asterisk $*(* *)$ denotes significance at the 5 (1) percent level.

The test statistics reported in the table present a somewhat mixed picture as is often the case with unit root tests. The LLC test statistics (often wrong-signed) clearly fail to reject a unit root throughout, while the IPS test rejects in some cases. Meanwhile, the Hadri test strongly rejects stationarity. Dropping the time effects would tilt the tests further in favor of unit roots. ${ }^{25}$ Qualitatively similar results obtain using the shorter sample period from 1992-2002. On balance, the tests are suggestive of the presence of unit roots in the panel.

This finding regarding possible non-stationarity in the panel data is not surprising when considering that the key variables include (log) nominal trade and the sums of (log) GDP and (log) GDP per capita between trading partners. Note that the income convergence hypothesis is not sufficient to rule out unit roots as the sum (not the difference) of $\ln \left(y_{\mathrm{i}}\right)$ and $\ln \left(y_{\mathrm{j}}\right)$ is the relevant income measure that enters the empirical equation. ${ }^{26}$ Given the possibility of unit roots in the panel data, panel cointegration tests were also conducted (see appendix). These tests strongly suggests that bilateral trade, GDP and GDP per capita between country trading pairs are cointegrated. For valid statistical inference with non-stationarity data, panel cointegration estimates relying on "dynamic OLS" or DOLS are used as a check on the standard OLS estimates. ${ }^{27}$

${ }^{25}$ Adding heterogeneous (i.e., country-pair specific) time trends would tilt the panel root test in the other direction - i.e., more in favor of stationarity. However, the gravity model equation that is usually considered does not make allowance for this.

${ }^{26}$ An implication of income convergence is that while $\ln \left(y_{\mathrm{i}}\right)$ and $\ln \left(y_{\mathrm{j}}\right)$ individually may be $I(1)$, the two series may be cointegrated-e.g., $\ln \left(y_{\mathrm{i}}\right)-\ln \left(y_{\mathrm{j}}\right)=U$, where $U$ is stationary or $I(0)$. But this would imply that their sum $U+2 \ln \left(y_{\mathrm{j}}\right)$ is still non-stationary.

${ }^{27}$ See appendix for a description of the dynamic panel estimation procedure. Note that OLS in this context refers to fixed effects (FE) estimation rather than least squares estimates with 


\section{Panel Cointegration Tests}

Given the results of the panel unit root tests, a battery of panel cointegration tests proposed by Pedroni $(2000,2001)$ are conducted to test whether a linear combination of the possibly non-stationary variables entering the gravity equation is stationary. Table A2 reports these test statistics based on residual-based tests that assume a null of no cointegration. The tests are conducted both with and with out time effects.

In the table, "panel" statistics impose common or pooled coefficients across individual panel units in deriving the corresponding test statistic, whereas the (less restrictive) group statistics represent the group mean of individual test statistics. Under the null, both sets of test statistics have a standard normal limiting distribution. Under the alternative, the panel $v$ statistic diverges to $+\infty$, requiring the use of a right-tail test (i.e., positive critical values), while the other statistics diverge to $-\infty$, requiring left-tail tests (i.e., negative critical values). The test statistics reject nearly unanimously, suggesting strong evidence of cointegration among the integrated variables identified above.

\begin{tabular}{|c|c|c|}
\hline \multicolumn{3}{|c|}{ Table A2. Panel Cointegration Statistics } \\
\hline Test Statistic & & \\
\hline Panel $v 7.17 * *$ & & $4.66^{* *}$ \\
\hline Panel $\rho$ & $-4.28 * *$ & $-5.28 * *$ \\
\hline Panel Phillips-Perron & $-9.14 * *$ & $-12.47 * *$ \\
\hline Panel ADF & $-5.24 * *$ & $-9.98 * *$ \\
\hline Group $\rho$ & 1.61 & -0.35 \\
\hline Group Phillips-Perron & $-7.69 * *$ & $-13.11 * *$ \\
\hline Group ADF & $-7.20 * *$ & $-12.45 * *$ \\
\hline Number of & & \\
\hline Regressors & $k=2$ & $k=2$ \\
\hline Time Effects & No & Yes \\
\hline
\end{tabular}

\section{Dynamic Panel Estimates}

For valid statistical inference with nonstationary panel data, cointegration estimators that correct for potential endogeneity bias and residual serial correlation are needed. The estimation here relies on the parametric approach favored by Kao and Chiang (2000) and Mark and Sul (2002) that extends Stock and Watson (1988) "dynamic" OLS (DOLS)

a "pooled constant." The critical estimation issue revolves around static versus dynamic panel FE estimation. 
estimator to a panel context. ${ }^{28}$ Specifically, the basic panel DOLS regression has the following form:

$\ln \left(\operatorname{Trade}_{i j t}\right)=\gamma_{i j}+\tau_{t}+\beta Z_{i j t}+\sum_{k=-m}^{m} \gamma_{k} \Delta Z_{i j t+k}+\alpha F T A_{i j t}+\delta_{t} E U_{i j t}+\lambda_{t} E M U_{i j t}+\varepsilon_{i j t} ;$

where $Z_{i j t}$ refers to the vector of integrated regressors consisting of partners" GDP and GDP per capita. By including leads and lags of the differenced series in (A1), DOLS addresses the potential bias produced by the OLS estimates. ${ }^{29}$ The standard errors, moreover, are adjusted to provide interpretable test statistics with the standard limiting distributions.

Panel DOLS estimates of the EMU effects on trade are shown in Table 1. Tables 2 in the text and A3 in the appendix estimate country-specific EMU effects, expressed in absolute and relative terms respectively, using panel DOLS.

${ }^{28}$ Comparing panel estimators that address endogeneity bias, Kao and Chiang (2000) find that DOLS outperforms the Phillips-Hansen "fully-modified" OLS (FMOLS) approach in finite samples.

${ }^{29}$ Estimation requires an appropriate choice for the truncation parameter $m$ determining the number of lead and lag terms. Data dependent methods described by Westerlund (2003), and applied here, for selecting the truncation point through testing down to a parsimonious representation have been shown to be produce reliable point estimates in finite samples. 


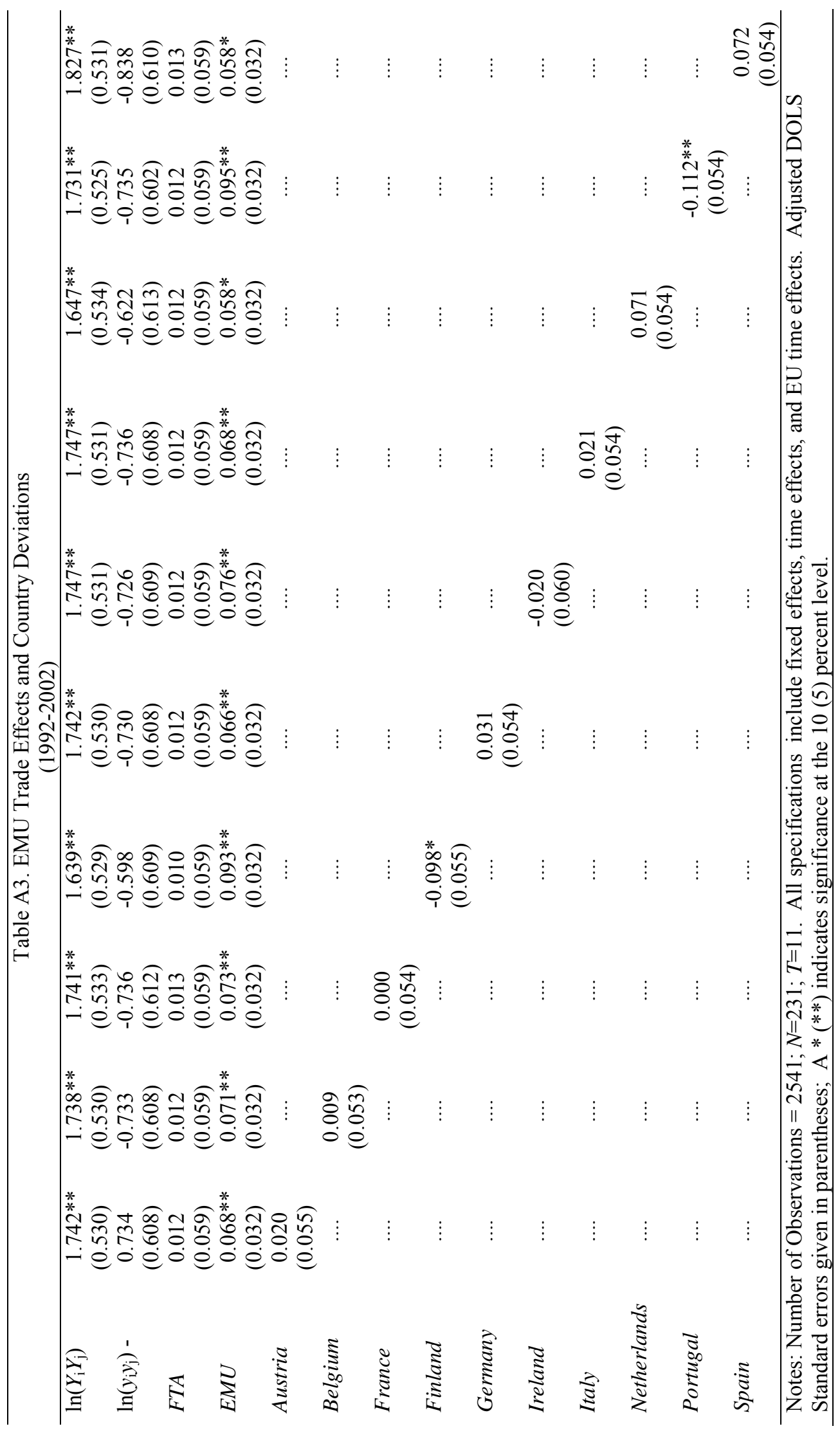




\section{REFERENCES}

Anderson, J., 1979, "A Theoretical Foundation for the Gravity Equation," American Economic Review, Vol. 69, No. 1, pp. 106-16.

Bayoumi, T., and B. Eichengreen, 1995, "Is Regionalism Simply A Diversion? Evidence from the Evolution of the EC and EFTA," NBER Working Paper 5283 (Cambridge, Massachusetts: National Bureau of Economic Research).

Bergstrand, J., 1985, “The Gravity Equation in International Trade: Some Microeconomics Foundations and Empirical Evidence," Review of Economics and Statistics, Vol. 67, No. 3, pp. 474-81.

Clark, P., and others, 2004, "Exchange Rate Volatility and Trade: Some New Evidence," (unpublished; Washington: International Monetary Fund). Available via the Internet at: http://www.imf.org/external/np/res/exrate/2004/eng/051904.pdf

Côté, A., 1994, "Exchange Rate Volatility and Trade: A Survey," International Department, Bank of Canada Working Paper 94-5.

Deardorff, A., 1984. "Testing Trade Theories and Predicting Trade Flows," in Handbook of International Economics, Vol. I, edited by R. Jones and P. Kenen (Amsterdam:

Elsevier Science Publishers), pp. 467-517.

, 1998, "Determinants of Bilateral Trade: Does Gravity Work in a Classical World?", in The Regionalization of the World Economy, edited by J. Frankel (Chicago: University of Chicago Press), pp. 7-22.

Dickey, D.A., and W.A. Fuller, 1979, "Distribution of the Estimators for Autoregressive Time Series with a Unit Root," Journal of the American Statistical Association, Vol. 74, pp. 427-31.

European Commission, 2002, "European Integration and the Functioning of Product Markets," European Economy, Special Report No. 2.

— 2003, Quarterly Report on the Euro Area, No. III (September).

— 2004, EMU after 5 Years, Directorate-General for Economic and Financial Affairs.

Faruqee, H., 1996, "Real Exchange Rates and the Pattern of Trade: Comparative Dynamics for North and South," Journal of International Money and Finance, Vol. 15, pp. 313-336.

Frankel, J., and A. Rose, 1997, “Is EMU More Justifiable Ex Post than Ex Ante?" European Economic Review, Vol. 41, Nos. 3-5, pp. 753-60. 
- 1998, "The Endogeneity of the Optimum Currency Area Criteria," The Economic Journal, Vol. 108, No. 449, pp. 1009-25.

- 2000, “An Estimate of the Effect of Currency Unions on Trade and Growth," NBER Working Paper 7857 (Cambridge, Massachusetts: National Bureau of Economic Research).

Fontagne, L., and M. Freudenberg, 1999, "Endogenous Symmetry of Shocks in a Monetary Union," Open Economies Review, Vol. 10, pp. 263-87.

Glick, R., and A.K. Rose, 2002, "Does A Currency Union Affect Trade? The Time Series

Evi dence," European Economic Review, Vol. 46, No. 6, pp. 1125-51.

Hadri, K., 2000, "Testing for Stationarity in Heterogeneous Panel Data," Econometrics Journal, Vol. 3, pp. 148-61.

Hsiao, C., 1986, Analysis of Panel Data (Cambridge: Cambridge University Press).

Im, K., M.H. Pesaran, and Y. Shin, 1997, “Testing for Unit Roots in Heterogeneous Panels" (unpublished; Department of Applied Economics, University of Cambridge: Cambridge). Available via the Internet at: http://www.econ.cam.ac.uk/faculty/pesaran/lm.pdf.

Kao, C., 1999, "Spurious Regression and Residual-Based Tests for Cointegration in Panel Data" Journal of Econometrics, Vol. 90, pp. 1-44

Kao, C., and M.-H. Chiang, 2000, "On the Estimation and Inference of A Cointegrated Regression in Panel Data," in Nonstationary Panels, Panel Cointegration, and Dynamic Panels, Advances in Econometrics, Vol. 15, edited by B. Baltagi (Amsterdam: JAI Press), pp. 179-222.

Kwiatkowski, D., and others, 1992, "Testing the Null Hypothesis of Stationarity Against the Alternative of A Unit Root,” Journal of Econometrics, Vol. 54, pp. 91-115.

Levin, A., C.-F. Lin, and C.-S. Chu, 2002, "Unit Root Tests in Panel Data: Asymptotic and Finite Sample Properties," Journal of Econometrics, Vol. 108, pp. 1-24.

Linnemann, H., 1966, An Econometric Study of International Trade Flows, (Amsterdam: North-Holland Publishers).

Mark, N.C., and D. Sul, 2002, "Cointegration Vector Estimation by Panel Dynamic OLS and Long-Run Money Demand,” NBER Working Paper 287 (Cambridge, Massachusetts: National Bureau of Economic Research). 
McKenzie, M., 1999, “The Impact of Exchange Rate Volatility on International Trade Flows," Journal of Economic Surveys, Vol. 13, No. 1, pp. 71-106.

Micco, A., E. Stein, and G. Ordonez, 2003, "The Currency Union Effect on Trade: Early Evidence from EMU," Economic Policy, Vol. 37, pp. 313-56.

Pedroni, P. 2000, "Fully Modified OLS for Heterogenous Cointegrated Panels," in Nonstationary Panels, Panel Cointegration, and Dynamic Panels, Advances in Econometrics, Vol. 15, edited by B. Baltagi (Amsterdam: JAI Press), pp. 93-130.

_ and Statistics, Vol. 83 (November), pp. 727-31.

Persson, T., 2001, "Currency Unions and Trade: How Large is the Treatment Effect?" Economic Policy, Vol. 33, pp. 435-48.

Phillips, P.C.B., and B.E. Hansen, 1990, "Statistical Inference in Instrumental Variables Regression with I(1) Processes," Review of Economic Studies, Vol. 57, pp. 99-125.

Rose, A.K., 2000, "One Money, One Market: Estimating the Effect of Common Currencies on Trade," Economic Policy, Vol. 30, pp. 7-45.

— 2004, "A Meta-Analysis of the Effect of Common Currencies on International Trade," NBER Working Paper 10373. (Cambridge, Massachusetts: National Bureau of Economic Research).

Schadler, S., 2003, "Charting a Course Toward Successful Euro Adoption," Finance \& Development, Vol. 41, No. 2, pp. 29-33.

Stock J. and M.Watson, 1988, Testing for Common Trends," Journal of the American Statistical Association, Vol. 83, pp. 1097-1107.

Tenreyro, S., 2001, “On the Causes and Consequences of Currency Unions" (unpublished; Cambridge, Massachusetts: Harvard University). Available via the Internet at: http://www.faculty.haas.berkeley.edu/arose/tenreyno.pdf.

U.K. Treasury, 2003, EMU and Trade, HM Treasury Study to Inform the Assessment of the Five Economic Tests (Norwich: HM Treasury Stationary Office).

Westerlund, J., 2003, "On the Feasibility of Panel Dynamic Estimators in Cointegrated Panels", (unpublished; Lund, Sweden: Lund University). 